Review

\title{
Prospects for a globally effective HIV-1 vaccine
}

\author{
Jean-Louis Excler ${ }^{\mathrm{a}, \mathrm{b}, *}$, Merlin L. Robb ${ }^{\mathrm{a}, \mathrm{b}}$, Jerome H. Kim ${ }^{\mathrm{a}}$ \\ a U.S. Military HIV Research Program, Walter Reed Army Institute of Research, Bethesda, MD, USA \\ ${ }^{\mathrm{b}}$ Henry M. Jackson Foundation for the Advancement of Military Medicine, Bethesda, MD, USA
}

\section{A R T I C L E I N F O}

\section{Article history:}

Available online $\mathrm{xxx}$

\section{Keywords:}

HIV-1

Vaccine

Correlates

Clinical trial

Efficacy

Public health

Licensure

\begin{abstract}
A B S T R A C T
A globally effective vaccine strategy must cope with the broad genetic diversity of HIV and contend with multiple transmission modalities. Understanding correlates of protection and the role of diversity in limiting protective vaccines with those correlates is key. RV144 was the first HIV-1 vaccine trial to demonstrate efficacy against HIV-1 infection. A correlates analysis compared vaccine-induced immune responses in vaccinated-infected and vaccinated-uninfected volunteers suggested that IgG specific for the V1V2 region of gp120 was associated with reduced risk of HIV-1 infection and that plasma Env IgA was directly correlated with infection risk. RV144 and recent NHP challenge studies suggest that Env is essential and perhaps sufficient to induce protective antibody responses against mucosally acquired HIV1. Whether RV144 immune correlates can apply to different HIV vaccines, to populations with different modes and intensity of transmission, or to divergent HIV-1 subtypes remains unknown. Newer primeboost mosaic and conserved sequence immunization strategies aiming at inducing immune responses of greater breadth and depth as well as the development of immunogens inducing broadly neutralizing antibodies should be actively pursued. Efficacy trials are now planned in heterosexual populations in southern Africa and MSM in Thailand. Although NHP challenge studies may guide vaccine development, human efficacy trials remain key to answer the critical questions leading to the development of a global HIV-1 vaccine for licensure.
\end{abstract}

(C) 2015 American Journal of Preventive Medicine and Elsevier Ltd. Published by Elsevier Ltd. All rights reserved.

\section{Introduction}

According to the UNAIDS, 35 million people were living with HIV-1 at the end of 2013, the vast majority being in Sub-Saharan Africa, with however dynamic epidemics in Asia [1]. Worldwide the number of people including children with new HIV-1 infections fell by $38 \%$ since 2001 [2]. Success in prevention programs can be ascribed to the strengthening and scaling-up of antiretroviral treatment along with existing and new prevention methods [3-6]. New prevention strategies include pre-exposure prophylaxis (PrEP) [7-10], antiretroviral treatment for prevention [10,11], and topical microbicides $[12,13]$.

Waning benefits of behavioral risk reduction for HIV-1, cultural opposition to male circumcision, still limited coverage of antiretroviral treatment, low adherence to PrEP [14], absence of PrEP efficacy in African women [15], and legal sanctions for sex worker and homosexuals may counterbalance the benefits achieved so far [16]. Although new HIV-1 infections fell worldwide

* Corresponding author at: U.S. Military HIV Research Program (MHRP), 6720-A Rockledge Drive, Suite 400, Bethesda, MD 20817, USA. Tel.: +63 9478937459

E-mail address: jexcler@hivresearch.org (J.-L. Excler). without HIV-1 vaccine intervention, critical exceptions to these trends are HIV epidemics among key populations such as people who inject drugs, young women and adolescents in southern sub-Saharan Africa, and young men who have sex in men (MSM) [17-19], and the increasingly complex HIV-1 genetic diversity $[20,21]$. Taken together, these considerations justify aggressive pursue development of a globally cost-effective HIV-1 vaccine against several HIV-1 strains and routes of transmission. The different HIV-1 vaccine approaches [22] and lessons learned from clinical trials [23] have recently been reviewed.

\section{What works and what doesn't for protection against HIV-1 acquisition}

Both antibodies and cell-mediated immune responses are thought to be important to prevent HIV-1 infection [24] in the mucosal compartment, the entry point for sexual transmission [25]. Table 1 summarizes the key animal challenge studies conducted with HIV-1 and SIV vaccines. Data from three non-human primate (NHP) studies [26-28] suggest that Env is a necessary component for successful protection from SIV acquisition. Two approaches are currently being pursued to elicit Env-specific antibody-mediated

Please cite this article in press as: Excler J-L, et al. Prospects for a globally effective HIV-1 vaccine. Vaccine (2015), http://dx.doi.org/10.1016/j.vaccine.2015.03.059 
Table 1

Key non-human primate and humanized mouse challenge studies of HIV-1 and SIV vaccines.

\begin{tabular}{|c|c|c|c|}
\hline Vaccines & Challenge & Immune responses and efficacy & References \\
\hline ALVAC-SIV/gp120 in alum or MF59 & Intrarectal SIVmac251 & $\begin{array}{l}\text { - Alum protected macaques from SIVmac251 acquisition while MF59 } \\
\text { did not despite its ability to elicit higher systemic T-cell and antibodies } \\
\text { responses } \\
\text { - Alum, in contrast, increased the frequency of plasmablasts } \\
\text { expressing the mucosal integrin } \alpha 4 \beta 7 \text { that positively correlated with } \\
\text { IgA responses to cyclic V2 in rectal mucosa } \\
\text { - In the alum group mucosal IgG to cyclic V2 correlated with lower risk } \\
\text { SIVmac } 251 \text { acquisition }\end{array}$ & {$[70]$} \\
\hline $\begin{array}{l}\text { DNA/Ad5 mosaic Gag or mosaic } \\
\text { heterologous envelope (Env) or } \\
\text { heterologous Env based on a natural } \\
\text { SIVmac } 239\end{array}$ & Intrarectal SIVsmE660 & $\begin{array}{l}\text { - SIVmac239 Env provided significant protection against acquisition, } \\
\text { whereas mosaic Env immunization did not achieve significance } \\
\text { - No difference in acquisition between Gag-immunized animals and } \\
\text { control animals } \\
\text { - For protection against acquisition, vaccine efficacy was } 69 \% \text { for } \\
\text { SIVmac239 Env } \\
\text { - Best control of acute VL in the mosaic Env arm, whereas mosaic Gag } \\
\text { arm showed the best long-term control } \\
\text { - Antibodies to the SIV envelope are necessary and sufficient to } \\
\text { prevent infection }\end{array}$ & [28] \\
\hline $\begin{array}{l}\text { AAV carrying b12, or } 2 \mathrm{G} 12 \text {, or } 4 \mathrm{E} 10 \text { or } 2 \mathrm{~F} 5 \\
\text { in humanized mice }\end{array}$ & Intravenous HIV-1 & $\begin{array}{l}\text { - Full protection with AAV carrying b12 } \\
\text { - Partial protection with AAV carrying } 2 \mathrm{G} 12 \text {, or } 4 \mathrm{E} 10 \text { or } 2 \mathrm{~F} 5\end{array}$ & [121] \\
\hline AAV carrying VRC07 in humanized mice & Intravaginal HIV-1 & - Full protection & [122] \\
\hline $\begin{array}{l}\text { Ad25/Ad5, Ad35/Ad5, Ad5/Ad5 expressing } \\
\text { SIVmac239 Gag }\end{array}$ & Intravenous SIVmac251 & $\begin{array}{l}\text { - Ad26/Ad5 regimen elicited a mean of } 8.6 \text { Gag epitopes per animal, } \\
\text { whereas Ad35/Ad5 elicited a mean of } 4.5 \text { epitopes per animal and } \\
\text { Ad5/Ad5 a mean of only } 2.2 \text { epitopes per animal } \\
\text { - Ad25/Ad5 reduced peak and setpoint viral load by } 1.43 \text { and } 2.6 \mathrm{log} \\
\text { and AIDS-related mortality as compared with controls } \\
\text { - Breadth and magnitude of Gag-specific cellular responses correlated } \\
\text { with control of setpoint viral loads }\end{array}$ & \\
\hline $\begin{array}{l}\text { Trivalent replication-incompetent rAd5 } \\
\text { vaccine expressing SIVmac239 Gag, Pol, } \\
\text { and Nef }\end{array}$ & Intrarectal SIVsmE660 & $\begin{array}{l}\text { - SIV-specific CD4+ and CD8+ responses by IFN- } \gamma \text { and ICS } \\
\text { - No efficacy on SIV acquisition or viral load }\end{array}$ & [135] \\
\hline $\begin{array}{l}\text { Chronically infected macaques with rAd5 } \\
\text { SIVmac239 Gag, Pol, Nef }\end{array}$ & Penile SIVmac251 & $\begin{array}{l}\text { - } \mathrm{CD} 8+\mathrm{T} \text {-cell responses in } 70 \% \text { of the animals } \\
\text { - No protection }\end{array}$ & [136] \\
\hline $\begin{array}{l}\text { SIVmac239 Env and Gag-Pol DNA } \\
\text { prime/rAd5 boost }\end{array}$ & $\begin{array}{l}\text { Intrarectal SIVmac251 and } \\
\text { SIVsmE660 }\end{array}$ & $\begin{array}{l}\text { - No protection against SIVmac251 infection, } 50 \% \text { of vaccinated } \\
\text { monkeys protected from SIVsmE660 } \\
\text { - One-log reduction in peak plasma virus RNA in Mamu-A*01 monkeys } \\
\text { - In Mamu-A*01-negative monkeys challenged with SIVsmE660, no } \\
\text { CD8+ T cell response or innate immune response was associated with } \\
\text { protection against virus acquisition } \\
\text { - Low levels of neutralizing antibodies and an envelope-specific CD4+ } \\
\text { T cell response were associated with vaccine protection in these } \\
\text { monkeys }\end{array}$ & [137] \\
\hline $\begin{array}{l}\text { Ad26/MVA and Ad26/Ad35 expressing } \\
\text { mosaic HIV-1 Env, Gag, and Pol }\end{array}$ & Intrarectal SHIV-SF162P3 & $\begin{array}{l}\text { - Protection against SHIV-SF162P3 acquisition correlated with NAb } \\
\text { titers against SF162 and ADCP, and trend with ADCD C3b complement } \\
\text { deposition } \\
\text { - No correlation with cyclic V2 peptides or gp70 V1V2 antibodies or } \\
\text { any measure of CD8+ T lymphocytes } \\
\text { - Modest effect on viral set point post-challenge likely linked to } \\
\text { Env-specific immune responses }\end{array}$ & [27] \\
\hline $\begin{array}{l}\text { DNA/MVA, MVA/MVA, Ad26/MVA, and } \\
\text { MVA/Ad26 SIVsme543 Gag-Pol and Env }\end{array}$ & Intrarectal SIVmac251 & $\begin{array}{l}\text { - Ad26/MVA and the MVA/Ad26 required three challenges to infect } \\
50 \% \text { of animals in each group, whereas only one challenge was } \\
\text { required to infect } 50 \% \text { of animals in the control group } \\
\text { - The regimens resulted in at least } 2.32 \text { and } 1.08 \text { log reductions of } \\
\text { mean set point viral load, respectively } \\
\text { - Protection against acquisition of infection correlated with } \\
\text { Env-specific binding ELISA antibodies, Tier- } 1 \text { neutralizing, and } \\
\text { V2-specific binding antibodies } \\
\text { - Virological control was correlated with Gag IFN- } \gamma \text { ELISPOT breadth }\end{array}$ & [26] \\
\hline $\begin{array}{l}\text { SIVconsv synthetic long peptides } \\
\text { adjuvanted (S) alone or DNA (D): SSS or } \\
\text { DDSS regimens }\end{array}$ & Intrarectal SIVmac251 & $\begin{array}{l}\text { - Strong polyfunctional CD4+ T-cell and modest CD8+ T-cell responses } \\
\text { of central memory T-cell phenotype } \\
\text { - SIVconsv-specific antibody responses were induced capable of } \\
\text { recognizing the Env glycoprotein } \\
\text { - } 2 / 6 \text { DDSS animals protected against infection, while all } 14 \text { animals in } \\
\text { the SSS and } 2 \text { control groups infected } \\
\text { - Vaccine induced SIV-specific IgG responses in mucosal washes } \\
\text { pre-challenge were highest in the two protected animals }\end{array}$ & [149] \\
\hline $\begin{array}{l}\text { Replication-competent rhesus } \\
\text { cytomegalovirus expression SIV Gag, } \\
\text { Rev/Tat/Nef, Env and Pol }\end{array}$ & $\begin{array}{l}\text { Intrarectal, intravaginal, } \\
\text { and intravenous } \\
\text { SIVmac239 }\end{array}$ & $\begin{array}{l}\text { - Protection of } 50 \% \text { of vaccinated animals } \\
\text { - Complete clearance of SIV in protected animals } \\
\text { - Effector memory SIV-specific CD4+ and CD8+ T-cell responses to all } \\
\text { SIV inserts, but little to no SIV Env-specific antibody responses }\end{array}$ & {$[152,153]$} \\
\hline
\end{tabular}

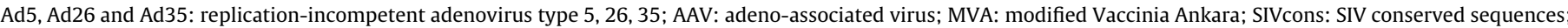
SHIV: chimeric simian-human immunodeficiency virus. 
protection: vaccines that induce potent and broadly reactive neutralizing antibodies (bNAbs) with activity against viruses which are common in human transmission (tier 2 viruses) or vaccines that induce antibodies which neutralize only lab adapted and less commonly transmitted HIV strains (Tier-1) but may block HIV-1 infection by non-neutralizing mechanisms [29,30].

\section{Vaccines that induce non-neutralizing antibodies}

The renewed interest in nonneutralizing antibodies (nNAbs) was prompted by the results of several HIV-1 vaccine efficacy trials and plausible mechanisms of action of nNAbs in protection against HIV-1 acquisition have recently been reviewed [31,32]. Neutralization is defined here in the standard TZM-bl pseudovirus assay [33].

Monomeric gp120 HIV-1 envelope proteins alone failed to protect high-risk volunteers against infection or disease progression in two previous efficacy trials, Vax003 [34] and Vax004 [35-37]. Vax004 tested AIDSVAX ${ }^{\circledR}$ B/B, a bivalent recombinant HIV-1 subtype B (GNE8 and MN) gp120 envelope glycoprotein subunit vaccine in US MSM and women at high risk for heterosexual transmission of HIV-1 [35]. High NAb levels against the easy-to-neutralize MN strain were however significantly inversely correlated with HIV-1 incidence while low levels against moredifficult-to-neutralize viruses did not, suggesting that level and breadth of elicited NAb were not sufficient for protection [36]. Interestingly, the level of vaccine-induced antibody-dependent cellular virus inhibition activity (ADCVI) correlated inversely with the rate of acquiring HIV-1 infection following vaccination. Moreover, ADCVI activity correlated poorly with NAb or CD4-gp120-blocking antibody activity measured.

Vax003 tested AIDSVAX ${ }^{\circledR} \mathrm{B} / \mathrm{E}$, a bivalent recombinant HIV-1 subtype B/E (A244 CRF01_AE and MN subtype B) gp120 envelope glycoprotein subunit vaccine in injecting drug users in Bangkok, Thailand. Antibody levels for gp120, A244 V2, A244 V3, blocking of A244 binding to CD4, and MN neutralization were not associated with infection risk [34].

In RV144 (reviewed in [38]), consisting of ALVAC-HIV (vCP1521) prime and AIDSVAX ${ }^{\circledR}$ gp120 B/E boost the modified intent-totreat analysis showed an estimated $31.2 \%$ efficacy after 42 months $[39,40], 60 \%$ at 12 months and $44 \%$ at 18 months post first vaccination, suggesting an early, but nondurable, vaccine effect [41]. NAb were observed against Tier-1 laboratory strains and was modulated by FcR polymorphisms [42]. CD4+ T cell-mediated, IFN- $\gamma$ ELISPOT positive responses were detected in $41 \%$ of the vaccinees and targeted the HIV-1 Env region, with $60 \%$ of vaccinees recognizing peptides derived from the Env V2 region, which includes the $\alpha 4 \beta 7$ integrin binding site [43,44]. MN and A244 Env binding antibodies were present in nearly all vaccinees, but dropped 15 -fold after 6 months. Antibody-dependent cell-mediated cytotoxicity (ADCC) in vaccine recipients and ADCC-mediating monoclonal $(\mathrm{mAb})$ antibodies from vaccinees have been described $[45,46]$.

The RV144 trial permitted a case-control study of correlates of risk for HIV acquisition. Plasma IgG binding antibody to scaffolded gp70 V1V2 CaseA2 envelope protein (HIV-1 subtype B) correlated inversely with risk, while Env plasma IgA correlated directly with risk. Neither low levels of V1V2 antibodies nor high levels of Env-specific IgA antibodies were associated with higher rates of infection than in the placebo group, ruling out the possibility of vaccine-induced enhancement. In vaccinees with low levels of Envspecific IgA antibodies, IgG avidity, ADCC, NAb to easy-to-neutralize viruses, and Env-specific CD4+ T cells, were inversely correlated with risk of infection [47-49]. RV144 antibodies to subtype A, C and CRF01_AE gp70 V1V2 scaffolded proteins also correlated inversely with risk [50], suggesting that the RV144 regimen might protect against heterosexual transmission of HIV strains heterologous (A and C) to the vaccine components. Two weeks post last vaccination $97 \%$ of RV144 studied plasma samples from vaccine recipients contained antibodies to V2 region synthetic peptides, falling to $19 \%$ at 48 weeks, suggesting that waning vaccine efficacy may be correlated to waning V2 antibody response.

The response to V3 CRF01_AE also inversely correlated with the risk of HIV infection in vaccine recipients with lower levels of Envspecific plasma IgA and neutralizing antibodies. In Vax003 and Vax004 (no protection), serum IgG responses targeted the same epitopes as in RV144 with the exception of an additional C1 reactivity in Vax003 and infrequent V2 reactivity in Vax004. These results along with a recent sieve analysis [51] generate the hypothesis that IgG to linear epitopes in the V2 and V3 regions of gp120 are part of a complex interplay of immune responses that contributed to protection in RV144 [52]. Correspondingly, in a SIVm251 low dose intrarectal challenge study of rhesus macaques, protection by an Ad26-MVA Gag-Pol-Env vaccine combination was associated with requirement for Env immunogen, anti-Env binding antibody, and V2 specific antibody responses [26]. In the Step and Phambili HIV-1 vaccine trials [53,54], the MRKAd5 HIV-1 Gag/Pol/Nef vaccine did not induce Env-specific antibody, and in HVTN 505 [55], the DNA/rAd5 Gag-Pol-Env HIV-1 vaccine regimen induced significantly lower levels of anti-V1V2 antibody, comparatively to RV144.

It was hypothesized that RV144 vaccine-induced antibodies to Env-V1V2 could selectively prevent HIV-1 infections by certain variants, and that this effect would be evident in the V1V2 region of breakthrough viruses. The sieve analysis examined the relationship between vaccine status and V1V2 sequence characteristics using HIV-1 sequences from breakthrough infections. Two vaccine-associated genetic signatures were identified in V2 corresponding to sites 169 and 181, further supporting the hypothesis that vaccination-induced immune responses directed against the V2 loop were associated with protection [56]. Monoclonal antibodies from RV144 vaccine recipients contact the V2 K169 residue, providing additional evidence that vaccine-induced antibodies correspond to the observed sieve effect. These V2-specific antibodies can mediate ADCC, neutralization of easy-to-neutralize viruses, and low-level virus capture [57,58]. In RV144, Env IgG3 was correlated with decreased risk of HIV infection, a response that declined rapidly compared to overall $\operatorname{IgG}$ responses $[59,60]$. A comparison of RV144 and Vax003 showed that Env-specific IgG3 and V1/V2 IgG3 response rates were higher in recipients of the RV144 vaccine compared to Vax003 vaccinees and conversely that IgG4 were considerably lower in RV144. These findings generate the hypothesis that V2 IgG plays a role in protection against HIV-1 acquisition [61] but do not distinguish between a mechanistic or non-mechanistic mechanisms of protection [62].

The RV144 correlates of risk (CoR) analysis suggests that an increase in magnitude, affinity, breadth, and importantly in frequency and durability of V2- and V3-specific antibodies of IgG3 and IgG1 subclasses may confer a higher and more durable rate of protection against HIV-1 infection. The induction of cross-reactive V1V2 specific IgG raises the hypothesis of cross-clade protection. However, issues of magnitude and durability attendant the original RV144 regimen must be addressed to improve responses in order to optimize hypothesis testing in future trials.

Additional booster vaccinations may increase antibody levels. Residual antibody responses against gp120 were detected 6-8 years post vaccination in RV144 vaccinees. Additional boosts increased plasma IgG gp120 and gp70 V1/V2 antibodies at titers higher than the RV144 peak time point while weak gp120 IgA responses were induced [63]. These HIV-specific IgG antibodies were also detected in rectal secretions while IgA were undetectable [64]. Surprisingly, the late boosts given to RV144 volunteers increased VH mutation frequency from that seen following the 
initial RV144 vaccine regimen (RV305 mean 5.50\%; RV144 mean $2.60 \%$ ) and expanded a population of antibodies with HCDR3 $>22$ amino acids. Similar to V1V2 bNAbs and other NAbs with long HCDR3s, these mAbs principally used D2/D3 and JH6 and are being characterized for neutralization capacity [65].

The use of potent adjuvants may also augment and shape antigen-specific antibody responses and contribute to antigen dose sparing. Several adjuvants have been tested in NHP and humans [66] showing a significant benefit of HIV envelope proteins formulated with either MF59 [67] and AS01 [68,69]. In macaques, alum protected macaques from SIVmac251 acquisition while MF59 did not despite its ability to elicit higher systemic T-cell and antibodies responses. Adjuvant-associated differences in the homing of plasmablasts and induction of key cellular signaling pathways may explain the acquisition effects [70]. The formulation of HIV-1 gp120 with L(MPLA) and alum induced significantly higher levels of neutralizing antibodies and T-cell lymphoproliferation compared to alum, MF59 or MPLA alone [71]; importantly antibodies to gp70 V1V2 (subtypes B, C and CRF01_AE) were induced more rapidly, to higher magnitude and with greater durability than alum-adjuvanted gp120 [71,72]. Formulation of antigens with solid nanoparticles may prolong the duration of antibody responses by increasing antigen deposition/retention locally in the tissues driving B-cell responses, enhancing dendritic cell antigen presentation [73], and development of CD4+ Tfh cells [74] that provide cytokines and signals required to initiate somatic hypermutation and affinity maturation for effective B-cell memory [75].

\section{Broadly neutralizing antibodies}

Unlike classical infectious diseases, such as mumps or rubella, natural HIV-1 infection does not induce protective immunity that eradicates (sterilizing) the virus or prevents progression to disease. Extending older studies [76-80], Hraber et al. showed that cross-clade NAb responses are commonly induced in response to infection by any virus clade. Nonetheless, neutralization was significantly greater when the plasma clade matched the clade of the virus tested. Features of the gp120 V1V2 loop, in particular, length, net charge, and number of $\mathrm{N}$-linked glycans, were associated with Env susceptibility and plasma neutralization potency in a manner consistent with neutralization escape being a force that drives viral diversification and plasma neutralization breadth [81]. The trimeric HIV-1 envelope glycoprotein is composed of variable regions that are immunodominant and induce type-specific NAbs of limited breadth, while the conserved regions such as the CD4 binding site are cryptic and poorly accessible to the immune system [82]. bNAbs develop in roughly $20 \%$ of HIV-infected after 2-3 years, but these bNAbs do not limit disease progression [83-87]. HIV-1 Env is covered with glycans that shield conserved epitopes from antibody recognition and evade the neutralizing antibody response [88]. An effective HIV-1 vaccine should therefore induce responses that differ qualitatively and quantitatively from that induced by natural infection, and able to cross-protect against various HIV-1 clades [89].

As a proof of concept, first and second generation bNAbs protect against intravaginal SHIV challenge [90-92], requiring high concentrations (25-50 mg/kg). Enhanced bNAbs confer protection at lower concentration ( 5 to $<1 \mathrm{mg} / \mathrm{kg}$ ) $[93,94]$. While the epitope specificity and putative germline sequences of the B-cell receptors of these antibodies have been defined, the challenge for epitopebased vaccine design is that only broadly conserved and exposed epitopes are suitable for vaccine targeting, but these epitopes, in their natural context, tend to elicit poor antibody responses [95]. When bNAb responses are elicited in the context of HIV infection, the corresponding broadly neutralizing monoclonal antibodies
(bnMAbs) tend to have uncommon features such as high levels of somatic mutations, insertions/deletions, long HCDR3 loops, post-translational modifications, polyreactivity, and rare structural motifs such as domain exchange [96-101]. Long HCDR3, though low in frequency, are present in the human mature naïve B-cell repertoire and generated by recombination during B-cell development [102]. A first step of the approach aims at fully defining the antibodies and epitopes associated with broadly HIV neutralization. This may dictate that immunogens and/or immunization protocols should be designed to increase antibody affinity maturation [103]. Alternatively, the high levels of somatic hypermutation may simply reflect the outcome of chronic antigen stimulation resulting from long-term HIV infection. Anti-Env antibodies from chronic infection in general, whether neutralizing or not, tend to have high levels of somatic hypermutation [104,105].

\subsection{Designing trimeric HIV-1 envelopes}

The challenge is to design, engineer and produce a pure stable envelope immunogen that mimics the antigenic profile of the functional envelope spike $[95,106,107]$. The first generation of HIV-1 gp120 immunogens designed were not, in general, well recognized by germline sequences of the PG9, PG16, and CH01 lineage bNAbs and failed to elicit bNAb in animals as most of the unmutated germline precursors of the bNAb do not bind to HIV- 1 spike proteins from most viral isolates. However, B cells producing bNAb precursors could not be recruited into immune responses by these immunogens (reviewed in [108]). Initially engineered trimeric envelope was unable to induce bNAb in animals [109]. Modification of the trimers including removal of individual glycans proximal to CD4-binding region [110], elimination of the glycosylation site near the gp41 loop [111], linker-stabilized gp140 trimeric envelopes [112] have resulted in improved immunogenicity but have not yielded the desired bNAb. The use of multivalent mixtures of natural HIV-1 subtype $C$ envelope uncleaved trimers elicited higher magnitude NAbs against Tier 1 viruses than individual trimers, but not against Tier 2 viruses [113]. A combination of mosaic envelopes tested increased the magnitude of NAbs but not the breadth the response in macaques [114]. Ad26/MVA and Ad26/Ad35 regimens expressing mosaic Env immunogens were able to protect macaques against SHIV-SF162P3 challenge. Protection was correlated with binding nNAbs (mosaic Env binding antibody, ADCP, and trend for antibody-dependent complement deposition), and with NAb titers against SF162 [27]. So far, no trimeric envelope induces bNAb in humans [83].

\subsection{B-cell lineage vaccine design}

Another approach is called B-cell lineage vaccine design and aims at engaging the naive B-cell repertoire residing in bone marrow and secondary lymphoid tissues. Specifically, one or more clonally related bNAb must be isolated and an antibody lineage constructed through inference that links the mutated bNAb-producing cell to its naive, germline ancestor. Recombinant antibody technology would express members of that bNAb lineage in order to select HIV-1 envelope constructs that optimally bind them. Those envelope constructs would be used as immunogens in a primeboost to engage the naive $B$ cell in vivo and iteratively stimulate B-cell "evolution" until bNAb-producing cells are elicited [115]. Liao et al. reported the isolation, evolution and structure of a bNAb from an African donor followed from the time of infection. The mature antibody, $\mathrm{CH} 103$, neutralized approximately 55\% of HIV-1 isolates, and its co-crystal structure with the HIV-1 envelope protein gp120 revealed a new loop-based mechanism of CD4-binding-site recognition. Virus and antibody gene sequencing revealed concomitant virus evolution and antibody maturation. Notably, the unmutated 
common ancestor of the $\mathrm{CH} 103$ lineage avidly bound the transmitted/founder HIV-1 envelope glycoprotein, and evolution of antibody neutralization breadth was preceded by extensive viral diversification in and near the $\mathrm{CH} 103$ epitope. These data describe the viral and antibody evolution leading to induction of a lineage of HIV-1 bNAbs, and provide insights into strategies to elicit similar antibodies by vaccination [116]. Doria-Rose et al. demonstrated that HIV-1 V1V2-directed neutralizing antibodies can develop relatively rapidly through initial selection of B cells with a long CDR H3, and limited subsequent somatic hypermutation. Identifying features of antigens able to engage naive B cells with such CDRH3 is a critical step in design of vaccines targeting V1V2. Such antigens could be screened for binding to the unmutated common ancestor versions of neutralizing antibodies as an indicator of the ability to engage an appropriate naive $B$ cell receptor. This work also suggests that although an appropriate trimeric V1V2 construct may elicit neutralizing V1V2 antibodies, sequential immunogens that mirror viral evolution may be needed to drive the development of breadth [117].

Wild-type gp120 proteins lack detectable affinity for predicted germline precursors of VRC01-class bNAbs, making them poor immunogens to prime a VRC01-class response. Jardine et al. used computation-guided, in vitro screening to engineer a germlinetargeting gp120 outer domain immunogen that binds to multiple VRC01-class bNAbs and their germline precursors. When multimerized on nanoparticles, this immunogen activates both germline and mature VRC01-class B cells [118]. Only nNAbs are elicited by Env immunization. In contrast to germline-reverted bNAbs, germline-reverted nNAbs recognize diverse recombinant Envs. In addition, nNAb B-cell progenitors become activated and internalize Env compared with bNAb B-cell progenitors. McGuire et al. show that rational immunogen modifications can reduce (and in certain cases eliminate) the activation of naïve $B$ cells that give rise to such nNAbs, while promoting the activation of naïve $B$ cells that give rise to germline-reverted VRC01-class bNAbs [103].

\subsection{Will broadly neutralizing antibodies protect against HIV-1 in humans?}

Whether bNAb will effectively confer protection against HIV acquisition in humans remains unknown. An alternative to inducing bNAb by vaccination with immunogens is to deliver these bnMAbs with viral vectors administered intramuscularly such as an adeno-associated virus (AAV) gene transfer vector expressing antibodies or antibody-like immunoadhesins having predetermined SIV specificity. SIV-specific molecules are endogenously synthesized in myofibers and passively distributed to the circulatory system. This approach generated long-lasting neutralizing activity in serum of macaques that observed complete protection against intravenous challenge with virulent SIVmac316 [119,120]. Similarly, full protection against intravenous HIV-1 challenge was observed in humanized mice receiving AAV carrying b12, while those receiving AAV carrying 2G12, 4E10 and 2F5 were partially protected [121]. Moreover, humanized mice receiving AAV carrying VRC07 were protected against repeated vaginal challenge with diverse HIV-1 strains [122]. An AAV vector carrying PG9 is now tested in a Phase I trial (clinicaltrials.gov: NCT01937455).

\section{Cell-mediated immune responses}

The rationale for $\mathrm{T}$-cell based vaccines has been recently reviewed [123-125]. T cell-based vaccine approaches have focused on three strategies: increasing the breadth of vaccine-induced responses [126] or increasing responses targeting only conserved regions of the virus [125] or using replication-competent viral vectors $[127,128]$. Cytotoxic T lymphocyte (CTL) responses targeting specific HIV proteins, in particular Gag, have been associated with relative control of viral replication and elite control of viremia in vivo (reviewed in $[124,129]$ ). In a SIVmac251 intravenous challenge model, breadth of Gag CTL epitope recognition correlated with control of peak and setpoint viremia [130].

\subsection{Natural HIV-1 sequences}

The Step (HVTN 502/Merck 023) [53,131] and Phambili (HVTN 503) [54] vaccine trials explored for the first time whether cell-mediated immune response-inducing vaccines could prevent infection or reduce post-infection plasma viral load. The Merck vaccine (MRKAd5 HIV-1) used in these two trials was a mixture of replication-defective Ad5 vectors expressing HIV-1 gag, pol, and nef subtype $B$ genes. The vaccine did not confer protection against HIV1 acquisition or disease progression measured by post-infection setpoint viral load (reviewed in [22,23]. There were excess HIV-1 infections in the vaccine group but statistical significance was not seen in the primary study; post hoc follow-up of data from both Step and Phambili rAd5 trials has suggested increased risk of HIV-1 infection in vaccine recipients. A sieve analysis showed evidence of vaccine-elicited immune pressure on the founder virus though no specific CD8+ CTL recognizing that epitope could be identified [132]. Vaccinees with HLA alleles associated with HIV-1 control had a significantly lower mean viral load over time [133]. Interestingly, the most highly conserved epitopes were detected at a lower frequency, suggesting that stronger responses to conserved sequences may be as important as breadth for protection [134]. The outcome of the Step trial was recapitulated in an Indian rhesus macaque study where animals vaccinated with a regimen similar to that employed in the Step trial were not protected against a heterologous SIVsmE660 challenge [135]. Rhesus macaques chronically infected with a host-range mutant Ad5 and immunized with a rAd5 SIVmac239 Gag/Pol/Nef vaccine were challenged with a series of escalating dose penile exposures to SIVmac251. Despite inducing CD8+ T-cell responses in 70\% of the monkeys the vaccine did not protect vaccinated animals from penile SIV challenge [136].

Aiming at inducing and improving breadth of both functional antibodies and cell-mediated responses [24] against three subtypes, a regimen with DNA vaccine prime composed of DNA plasmids encoding Gag, Pol, and Nef from HIV-1 subtype B and Env from subtypes A, B, and C and replication-defective rAd5-HIV-1 vaccine boost containing a mixture of four rAd5 vectors encoding the HIV-1 subtype B Gag-Pol and Env matching the DNA Env components was tested in the HVTN 505 vaccine efficacy trial. In contrast with MRKAd5 that did not contain an env gene, the vaccine contained three envelope genes. The vaccine regimen induced polyfunctional CD4+ and CD8+ T-cells, multi-clade anti-Env binding antibodies, and Nab against easy to neutralize Tier 1 viruses. The Phase IIB trial (HVTN 505) was stopped for futility, showing no efficacy and no statistically significant effect on viral load and a non-significant excess of HIV infection in the vaccinated group [55]. This prime-boost vaccine regimen failed to protect NHP against SIVmac251 infection, but $50 \%$ of vaccinated monkeys were protected from infection with SIVsmE660 with about a one-log reduction in peak plasma virus RNA in Mamu-A*01-positive animals, suggesting a role of CTL in the control of SIV replication. However, low levels of $\mathrm{NAb}$ and envelope-specific CD4+ T-cell responses were associated with animal protection [137].

Other approaches with DNA prime and MVA boost have elicited broad and potent T-cell responses and deserve further development [138]. Interestingly, heterologous vector primeboost regimens enhance immunity by increasing the magnitude, onset and multi-functionality of the insert-specific cell-mediated immune responses compared to homologous regimens [139]. 


\subsection{Mosaic HIV-1 immunogens}

Polyvalent mosaic immunogens derived by recombination of natural HIV-1 strains are designed to induce cellular immune responses that recognize genetically diverse circulating virus isolates. Increasing the breadth and depth of epitope recognition may contribute both to protection against infection by genetically diverse viruses and to the control of variant viruses that emerge as they mutate away from recognition by cytotoxic $\mathrm{T}$ lymphocytes [140].

Mosaic HIV-1 Gag, Pol and Env antigens expressed by Ad26 vectors markedly augmented both the breadth and depth without compromising the magnitude of antigen-specific T lymphocyte responses as compared with consensus or natural sequence HIV-1 antigens in rhesus monkeys [141]. As described above, Ad26/MVA and Ad26/Ad35 vector-based vaccines expressing HIV-1 mosaic Env, Gag, and Pol afforded protection against intrarectal SHIVSF162P3 challenge, correlated with antibody responses, the vaccine regimens had only a modest effect on viral setpoint post-challenge [27]. In contrast, similar vector regimens expressing SIVsmE543 antigens afforded $>2$ log reductions of setpoint viral loads following heterologous SIVmac251 challenges [26]. However, a head-to-head comparison in humans of mosaic and natural sequences should deserve consideration.

\subsection{HIV-1 conserved sequences}

An alternative to multivalent wild-type or mosaic vaccines is the use of conserved element immunogens as a novel and effective strategy to broaden responses against highly diverse pathogens by avoiding decoy epitopes, while focusing responses to critical viral elements for which few escape pathways exist [126,142-144]. Priming with conserved elements boosted with the complete immunogen induced broad cellular and humoral immunity focused on the conserved regions of the virus [145]. In contrast, full-length HIV-1 immunogens induced greater magnitude and comparable breadth of T-lymphocyte responses to conserved HIV-1 regions compared with conserved-region-only HIV-1 immunogens in rhesus monkeys [146].

Conserved sequences and immune responses have been characterized in animals [147,148], conferring partial protection against SIVmac251 in macaques [149]. In humans, a combination of DNA, ChAd63 and MVA vectors was found safe [150] and immunogenic, inducing high levels of effector $\mathrm{T}$ cells that recognized virus-infected autologous CD4+ cells. In vitro inhibition of HIV-1 replication was mediated by Gag- and Pol-specific effector CD8+ T cells targeting epitopes that are subdominant in natural infection [151].

\subsection{Use of replicating vector}

A replication-competent rhesus cytomegalovirus vaccine expressing SIV proteins induced and maintained high frequency of SIV-specific CD4+ and CD8+ T-cell effector memory (TEM) responses at extra-lymphoid sites without measurable antibody responses to SIV. Half of vaccinated monkeys showed a stringent control of three routes of transmission: intrarectal, intravaginal, or intravenous SIVmac239. The outcome of challenge was predicted by peak SIV-specific CD8+ TEM frequencies in peripheral blood pre-challenge [152,153].

Whether these new $\mathrm{T}$ cell-based vaccines (Table 1 ) will be transitioned to human efficacy trials is unknown, though the conservation of particular cytotoxic epitopes does make them good candidates for a global HIV-1 vaccine.

\section{Conclusions}

RV144 was the first HIV-1 vaccine trial to demonstrate efficacy against HIV-1 infection. Put in perspective, RV144 and recent NHP challenge studies suggest that Env is essential and perhaps sufficient to induce protective antibody responses against HIV-1 acquisition at the mucosal site of entry. Whether the CoR identified in RV144 can be extended to other populations with different modes and intensity of transmission and against increasing complex HIV-1 strain recombinations remains to be demonstrated. While the RV144 immunization strategy remains a priority for future efficacy trials, newer prime-boost mosaic and conserved sequence immunization strategies aiming at inducing immune responses or greater breadth and depth as well as the development of immunogens inducing broadly neutralizing antibodies should be actively pursued and tested in humans as soon as available. Efficacy trials are now planned in heterosexual populations in southern Africa and MSM in Thailand and possibly in China. Although NHP challenge studies may guide vaccine development, human efficacy trials remain key to answer the critical questions leading to the development of a global HIV-1 vaccine for licensure [154].

\section{Disclaimer}

The opinions herein are those of the authors and should not be construed as official or representing the views of the U.S. Department of Defense or Department of the Army.

\section{Authors' contribution}

All authors equally contributed to the preparation of this manuscript and approved the final version of this manuscript.

\section{Acknowledgments}

The preparation of this manuscript was supported in part by an Interagency Agreement Y1-AI-2642-12 between U.S. Army Medical Research and Materiel Command (USAMRMC) and the National Institutes of Allergy and Infectious Diseases. In addition, this work was supported by a cooperative agreement (W81XWH-07-2-0067) between the Henry M. Jackson Foundation for the Advancement of Military Medicine, Inc., and the U.S. Department of Defense (DOD).

This article is being published concurrently in the American Journal of Preventive Medicine and Vaccine. The articles are identical except for stylistic changes in keeping with each journal's style. Either of these versions may be used in citing this article. Publication of this article was supported by Merck and Novartis.

\section{References}

[1] Nitayaphan S, Ngauy V, O'Connell R, Excler JL. HIV epidemic in Asia: optimizing and expanding vaccine development. Expert Rev Vaccines 2012;11:805-19.

[2] UNAIDS. The Gap report. Switzerland: Geneva; 2014.

[3] McCoy SI, Kangwende RA, Padian NS. Behavior change interventions to prevent HIV infection among women living in low and middle income countries: a systematic review. AIDS Behav 2010;14:469-82.

[4] Dutta A, Wirtz AL, Baral S, Beyrer C, Cleghorn FR. Key harm reduction interventions and their impact on the reduction of risky behavior and HIV incidence among people who inject drugs in low-income and middle-income countries. Curr Opin HIV AIDS 2012; 7:362-8. 
[5] Wamai RG, Morris BJ, Bailis SA, Sokal D, Klausner JD, Appleton R, et al. Male circumcision for HIV prevention: current evidence and implementation in sub-Saharan Africa. J Int AIDS Soc 2011;14:49.

[6] Chi BH, Adler MR, Bolu O, Mbori-Ngacha D, Ekouevi DK, Gieselman A, et al. Progress, challenges, and new opportunities for the prevention of mother-tochild transmission of HIV under the US President's Emergency Plan for AIDS Relief. J Acquir Immune Defic Syndr 2012;60(Suppl. 3):S78-87.

[7] Kim SC, Becker S, Dieffenbach C, Hanewall BS, Hankins C, Lo YR, et al. Planning for pre-exposure prophylaxis to prevent HIV transmission: challenges and opportunities. J Int AIDS Soc 2010;13:24

[8] Grant RM, Lama JR, Anderson PL, McMahan V, Liu AY, Vargas L, et al. Preexposure chemoprophylaxis for HIV prevention in men who have sex with men. N Engl J Med 2010;363:2587-99.

[9] Choopanya K, Martin M, Suntharasamai P, Sangkum U, Mock PA, Leethochawalit $M$, et al. Antiretroviral prophylaxis for HIV infection in injecting drug users in Bangkok, Thailand (the Bangkok Tenofovir Study): a randomised, double-blind, placebo-controlled phase 3 trial. Lancet 2013;381:2083-90.

[10] Mastro TD, Sista N, Abdool-Karim Q. ARV-based HIV prevention for women where we are in 2014. J Int AIDS Soc 2014;17:19154

[11] Cohen MS, Holmes C, Padian N, Wolf M, Hirnschall G, Lo YR, et al. HIV treatment as prevention: how scientific discovery occurred and translated rapidly into policy for the global response. Health Aff (Millwood) 2012;31: 1439-49.

[12] Krakower D, Mayer KH. Promising prevention approaches: tenofovir gel and prophylactic use of antiretroviral medications. Curr HIV/AIDS Rep 2011;8:241-8

[13] Abdool Karim Q, Abdool Karim SS, Frohlich JA, Grobler AC, Baxter C, Mansoor LE, et al. Effectiveness and safety of tenofovir gel, an antiretroviral microbicide, for the prevention of HIV infection in women. Science 2010;329:1168-74.

[14] Grant RM, Anderson PL, McMahan V, Liu A, Amico KR, Mehrotra M, et al. Uptake of pre-exposure prophylaxis, sexual practices, and HIV incidence in men and transgender women who have sex with men: a cohort study. Lancet Infect Dis 2014;14:820-9.

[15] Van Damme L, Corneli A, Ahmed K, Agot K, Lombaard J, Kapiga S, et al. Preexposure prophylaxis for HIV infection among African women. N Engl J Med 2012;367:411-22.

[16] Fauci AS, Marston HD. Ending AIDS - is an HIV vaccine necessary? N Engl J Med 2014;370:495-8.

[17] Beyrer C, Abdool Karim Q. The changing epidemiology of HIV in 2013. Curr Opin HIV AIDS 2013:8:306-10.

[18] Beyrer C, Baral SD, van Griensven F, Goodreau SM, Chariyalertsak S, Wirtz AL, et al. Global epidemiology of HIV infection in men who have sex with men. Lancet 2012;380:367-77.

[19] Baral SD, Poteat T, Stromdahl S, Wirtz AL, Guadamuz TE, Beyrer C. Worldwide burden of HIV in transgender women: a systematic review and meta-analysis. Lancet Infect Dis 2013;13:214-22.

[20] Hemelaar J, Gouws E, Ghys PD, Osmanov S. Global trends in molecular epidemiology of HIV-1 during 2000-2007. AIDS 2011;25:679-89.

[21] Hemelaar J. Implications of HIV diversity for the HIV-1 pandemic. J Infect 2013;66:391-400

[22] Excler JL, Robb ML, Kim JH. HIV-1 vaccines: challenges and new perspectives. Hum Vaccines Immunother 2014;10:1734-46

[23] Excler JL, Tomaras GD, Russell ND. Novel directions in HIV-1 vaccines revealed from clinical trials. Curr Opin HIV AIDS 2013;8:421-31.

[24] Walker BD, Ahmed R, Plotkin S. Moving ahead an HIV vaccine: use both arms to beat HIV. Nat Med 2011;17:1194-5

[25] O’Connell RJ, Excler JL. HIV vaccine efficacy and immune correlates of risk. Curr HIV Res 2013;11:450-63.

[26] Barouch DH, Liu J, Li H, Maxfield LF, Abbink P, Lynch DM, et al. Vaccine protection against acquisition of neutralization-resistant SIV challenges in rhesus monkeys. Nature 2012;482:89-93.

[27] Barouch DH, Stephenson KE, Borducchi EN, Smith K, Stanley K, McNally AC, et al. Protective efficacy of a global HIV-1 mosaic vaccine against heterologous SHIV challenges in rhesus monkeys. Cell 2013;155:531-9.

[28] Roederer M, Keele BF, Schmidt SD, Mason RD, Welles HC, Fischer W, et al. Immunological and virological mechanisms of vaccine-mediated protection against SIV and HIV. Nature 2014;505:502-8

[29] Zolla-Pazner S. A critical question for HIV vaccine development: which antibodies to induce? Science 2014:345:167-8.

[30] Mascola JR. HIV/AIDS: allied responses. Nature 2007;449:29-30.

[31] Su B, Moog C. Which antibody functions are important for an HIV vaccine? Front Immunol 2014:5:289.

[32] Excler JL, Ake J, Robb ML, Kim JH, Plotkin SA. Nonneutralizing functional antibodies: a new "old" paradigm for HIV vaccines. Clin Vaccine Immunol 2014;21:1023-36.

[33] Sarzotti-Kelsoe M, Bailer RT, Turk E, Lin CL, Bilska M, Greene KM, et al. Optimization and validation of the TZM-bl assay for standardized assessment of neutralizing antibodies against HIV-1. J Immunol Methods 2014;409: $131-46$

[34] Pitisuttithum P, Gilbert P, Gurwith M, Heyward W, Martin M, van Griensven F, et al. Randomized, double-blind, placebo-controlled efficacy trial of a bivalent recombinant glycoprotein 120 HIV-1 vaccine among injection drug users in Bangkok, Thailand. J Infect Dis 2006;194:1661-71.
[35] Flynn NM, Forthal DN, Harro CD, Judson FN, Mayer KH, Para MF. Placebocontrolled phase 3 trial of a recombinant glycoprotein 120 vaccine to prevent HIV-1 infection. J Infect Dis 2005;191:654-65.

[36] Gilbert PB, Peterson ML, Follmann D, Hudgens MG, Francis DP, Gurwith M et al. Correlation between immunologic responses to a recombinant glycoprotein 120 vaccine and incidence of HIV-1 infection in a phase 3 HIV-1 preventive vaccine trial. J Infect Dis 2005;191:666-77.

[37] Gilbert PB, Ackers ML, Berman PW, Francis DP, Popovic V, Hu DJ, et al. HIV-1 virologic and immunologic progression and initiation of antiretroviral therapy among HIV-1-infected subjects in a trial of the efficacy of recombinant glycoprotein 120 vaccine. J Infect Dis 2005;192:974-83.

[38] Kim JH, Excler JL, Michael NL. Lessons from the RV144 Thai phase III HIV1 vaccine trial and the search for correlates of protection. Annu Rev Med 2015;66:423-37.

[39] Rerks-Ngarm S, Pitisuttithum P, Nitayaphan S, Kaewkungwal J, Chiu J, Paris $\mathrm{R}$, et al. Vaccination with ALVAC and AIDSVAX to prevent HIV-1 infection in Thailand. N Engl J Med 2009;361:2209-20.

[40] Gilbert PB, Berger JO, Stablein D, Becker S, Essex M, Hammer SM, et al. Statistical interpretation of the RV144 HIV vaccine efficacy trial in Thailand: a case study for statistical issues in efficacy trials. J Infect Dis 2011;203:969-75.

41] Robb ML, Rerks-Ngarm S, Nitayaphan S, Pitisuttithum P, Kaewkungwal ], Kunasol P, et al. Risk behaviour and time as covariates for efficacy of the HIV vaccine regimen ALVAC-HIV (vCP1521) and AIDSVAX B/E: a post-hoc analysis of the Thai phase 3 efficacy trial RV 144. Lancet Infect Dis 2012;12:531-7.

[42] Forthal DN, Gilbert PB, Landucci G, Phan T. Recombinant gp120 vaccineinduced antibodies inhibit clinical strains of HIV-1 in the presence of FC receptor-bearing effector cells and correlate inversely with HIV infection rate. J Immunol 2007;178:6596-603.

[43] Cicala C, Martinelli E, McNally JP, Goode DJ, Gopaul R, Hiatt J, et al. The integrin alpha4beta7 forms a complex with cell-surface CD4 and defines a T-cel subset that is highly susceptible to infection by HIV-1. Proc Natl Acad Sci U S A 2009; 106:20877-82.

[44] Arthos J, Cicala C, Martinelli E, Macleod K, Van Ryk D, Wei D, et al. HIV 1 envelope protein binds to and signals through integrin alpha4beta7, the gut mucosal homing receptor for peripheral T cells. Nat Immunol 2008;9: 301-9.

[45] Karnasuta C, Paris RM, Cox JH, Nitayaphan S, Pitisuttithum P, Thongcharoen P, et al. Antibody-dependent cell-mediated cytotoxic responses in participants enrolled in a phase I/II ALVAC-HIV/AIDSVAX B/E prime-boost HIV-1 vaccine trial in Thailand. Vaccine 2005;23:2522-9.

[46] Bonsignori M, Pollara J, Moody MA, Alpert MD, Chen X, Hwang KK, et al Antibody-dependent cellular cytotoxicity-mediating antibodies from an HIV1 vaccine efficacy trial target multiple epitopes and preferentially use the VH1 gene family. J Virol 2012;86:11521-32.

[47] Haynes BF, Gilbert PB, McElrath MJ, Zolla-Pazner S, Tomaras GD, Alam SM et al. Immune-correlates analysis of an HIV-1 vaccine efficacy trial. N Engl Med 2012;366:1275-86

[48] Zolla-Pazner S, deCamp AC, Cardozo T, Karasavvas N, Gottardo R, Williams $\mathrm{C}$, et al. Analysis of V2 antibody responses induced in vaccinees in the ALVAC/AIDSVAX HIV-1 vaccine efficacy trial. PLOS ONE 2013;8:e53629.

[49] Karasavvas N, Billings E, Rao M, Williams C, Zolla-Pazner S, Bailer RT, et al. The Thai Phase III HIV Type 1 Vaccine trial (RV144) regimen induces antibodies that target conserved regions within the V2 loop of gp120. AIDS Res Hum Retroviruses 2012;28:1444-57.

[50] Zolla-Pazner S, Decamp A, Gilbert PB, Williams C, Yates NL, Williams WT, et al. Vaccine-induced IgG antibodies to V1V2 regions of multiple HIV-1 subtypes correlate with decreased risk of HIV-1 infection. PLOS ONE 2014:9:e87572.

[51] Rolland M, Edlefsen PT, Gottardo R, Montefiori DC, Zolla-Pazner S, Moody A et al. Genetic and immunological evidence for a role of Env-V3 antibodies in the RV144 trial. In: Abstract P03.73 LB, AIDS Vaccine 2013. 2013.

[52] Gottardo R, Bailer RT, Korber BT, Gnanakaran S, Phillips J, Shen X, et al. Plasma IgG to linear epitopes in the V2 and V3 regions of HIV-1 gp120 correlate with a reduced risk of infection in the RV144 vaccine efficacy trial. PLOS ONE 2013:8:e75665

[53] Buchbinder SP, Mehrotra DV, Duerr A, Fitzgerald DW, Mogg R, Li D, et al. Efficacy assessment of a cell-mediated immunity HIV-1 vaccine (the step study): a double-blind, randomised, placebo-controlled, test-of-concept trial. Lancet 2008;372:1881-93

[54] Gray GE, Allen M, Moodie Z, Churchyard G, Bekker LG, Nchabeleng M, et al. Safety and efficacy of the HVTN 503/Phambili study of a clade-B-based HIV1 vaccine in South Africa: a double-blind, randomised, placebo-controlled test-of-concept phase 2b study. Lancet Infect Dis 2011;11:507-15.

[55] Hammer SM, Sobieszczyk ME, Janes H, Karuna ST, Mulligan MJ, Grove D, et al. Efficacy trial of a DNA/rAd5 HIV-1 preventive vaccine. N Engl J Med 2013;369:2083-92

[56] Rolland M, Edlefsen PT, Larsen BB, Tovanabutra S, Sanders-Buell E, Hertz T, et al. Increased HIV-1 vaccine efficacy against viruses with genetic signatures in Env V2. Nature 2012:490:417-20.

[57] Liao HX, Bonsignori M, Alam SM, McLellan JS, Tomaras GD, Moody MA, et al. Vaccine induction of antibodies against a structurally heterogeneous site of immune pressure within HIV-1 envelope protein variable regions 1 and 2 . Immunity 2013;38:176-86

[58] Liu P, Yates NL, Shen X, Bonsignori M, Moody MA, Liao HX, et al. Infectious virion capture by HIV-1 gp120-specific IgG from RV144 vaccinees. J Virol 2013:87:7828-36. 
[59] Yates NL, Liao HX, Fong Y, Decamp A, Vandergrift NA, Williams WT, et al. Vaccine-induced Env V1-V2 IgG3 correlates with lower HIV-1 infection risk and declines soon after vaccination. Sci Transl Med 2014;6:228ra39.

[60] Chung AW, Ghebremichael M, Robinson H, Brown E, Choi I, Lane S, et al. Polyfunctional Fc-effector profiles mediated by IgG subclass selection distinguish RV144 and VAX003 vaccines. Sci Transl Med 2014;6(228):ra38.

[61] O'Connell RJ, Kim JH, Excler JL. The HIV-1 gp120 V1V2 loop: structure, function and importance for vaccine development. Expert Rev Vaccines 2014:1-12.

[62] Plotkin SA, Gilbert PB. Nomenclature for immune correlates of protection after vaccination. Clin Infect Dis 2012;54:1615-7.

[63] Karasavvas N, Karnasuta C, Ngauy V, Vasan S, Tricharavoj R, de Souza MS, et al. Investigation of antibody responses induced in RV305 a late boost vaccination of HIV-1 uninfected volunteers that participated in RV144, a Thai trial. In: P03.68LB, AIDS Vaccine 2013. 2013.

[64] Akapirat S, Karnasuta C, Madnote S, Savadsuk H, Puangkaew J, Rittiroongrad S, et al. HIV-specific antibody in rectal secretions following late boosts in RV144 participants (RV305). In: OA11.05, HIV R4P. 2014.

[65] Moody MA, Easterhoff D, Gurley TC, Whitesides JF, Marshall DJ, Foulger A, et al. Induction of antibodies with long variable heavy third complementarity determining regions by repetitive boosting with AIDSVAX ${ }^{\circledR} \mathrm{B} / \mathrm{E}$ in RV144 vaccinees. In: OA12.06 LB, HIV R4P. 2014.

[66] Mastelic B, Garcon N, Del Giudice G, Golding H, Gruber M, Neels P, et al. Predictive markers of safety and immunogenicity of adjuvanted vaccines. Biologicals 2013;41:458-68.

[67] O'Hagan DT, Ott GS, De Gregorio E, Seubert A. The mechanism of action of MF59 - an innately attractive adjuvant formulation. Vaccine 2012;30: 4341-8.

68] Leroux-Roels I, Koutsoukos M, Clement F, Steyaert S, Janssens M, Bourguignon $\mathrm{P}$, et al. Strong and persistent CD4+ T-cell response in healthy adults immunized with a candidate HIV-1 vaccine containing gp120, Nef and Tat antigens formulated in three adjuvant systems. Vaccine 2010;28:7016-24.

[69] Garcon N, Van Mechelen M. Recent clinical experience with vaccines using MPL- and QS-21-containing adjuvant systems. Expert Rev Vaccines 2011;10:471-86.

[70] Vaccari M, Gordon SN, Fourati S, Schifanella L, Cameron M, Keele BF, et al Adjuvant dependent mucosal V2 responses and RAS activation in vaccine induced protection from SIVmac251 acquisition. In: OA25.01. HIV R4P. 2014.

[71] McElrath MJ. Selection of potent immunological adjuvants for vaccine construction. Semin Cancer Biol 1995:6:375-85.

[72] Rao M, Onkar S, Peachman K, Padilla-Sanchez V, Yamini G, Jobe O, et al. Potent V2-specific antibodies induced in humans using liposome-encapsulated HIV1 gp120 recognize a well-exposed V2 epitope on envelope trimer. In: Abstract 2049. Keystone, HIV Vaccines: Adaptive Immunity and Beyond. 2014

[73] Moon JJ, Suh H, Bershteyn A, Stephan MT, Liu H, Huang B, et al. Interbilayercrosslinked multilamellar vesicles as synthetic vaccines for potent humoral and cellular immune responses. Nat Mater 2011;10:243-51.

[74] Zhao L, Seth A, Wibowo N, Zhao CX, Mitter N, Yu C, et al. Nanoparticle vaccines. Vaccine 2014;32:327-37.

[75] Nutt SL, Tarlinton DM. Germinal center B and follicular helper T cells: siblings, cousins or just good friends? Nat Immunol 2011;12:472-7.

[76] Moore JP, Cao Y, Leu J, Qin L, Korber B, Ho DD. Inter- and intraclade neutralization of human immunodeficiency virus type 1: genetic clades do not correspond to neutralization serotypes but partially correspond to gp120 antigenic serotypes. J Virol 1996;70:427-44

[77] Mascola JR, Louder MK, Surman SR, Vancott TC, Yu XF, Bradac J, et al. Human immunodeficiency virus type 1 neutralizing antibody serotyping using serum pools and an infectivity reduction assay. AIDS Res Hum Retroviruses 1996;12:1319-28

[78] Mascola JR, Louwagie J, McCutchan FE, Fischer CL, Hegerich PA, Wagner $\mathrm{KF}$, et al. Two antigenically distinct subtypes of human immunodeficiency virus type 1: viral genotype predicts neutralization serotype. J Infect Dis 1994;169:48-54.

[79] Nyambi PN, Nkengasong J, Lewi P, Andries K, Janssens W, Fransen K, et al Multivariate analysis of human immunodeficiency virus type 1 neutralization data. J Virol 1996;70:6235-43

[80] Weber J, Fenyo EM, Beddows S, Kaleebu P, Bjorndal A. Neutralization serotypes of human immunodeficiency virus type 1 field isolates are not predicted by genetic subtype. The WHO Network for HIV Isolation and Characterization. J Virol 1996;70:7827-32.

81] Hraber P, Korber BT, Lapedes AS, Bailer RT, Seaman MS, Gao H, et al. Impact of clade, geography, and age of the epidemic on HIV-1 neutralization by antibodies. J Virol 2014;88:12623-43.

[82] Koff WC. HIV vaccine development: challenges and opportunities towards solving the HIV vaccine-neutralizing antibody problem. Vaccine 2012;30:4310-5

[83] Mascola JR, Haynes BF. HIV-1 neutralizing antibodies: understanding nature's pathways. Immunol Rev 2013;254:225-44.

[84] Tomaras GD, Haynes BF. Lessons from babies: inducing HIV-1 broadly neutralizing antibodies. Nat Med 2014;20:583-5.

[85] Goo L, Chohan V, Nduati R, Overbaugh J. Early development of broadly neutralizing antibodies in HIV-1-infected infants. Nat Med 2014;20:655-8.

[86] Simek MD, Rida W, Priddy FH, Pung P, Carrow E, Laufer DS, et al. Human immunodeficiency virus type 1 elite neutralizers: individuals with broad and potent neutralizing activity identified by using a high-throughput neutralization assay together with an analytical selection algorithm. J Virol 2009;83:7337-48.
[87] Stamatatos L, Morris L, Burton DR, Mascola JR. Neutralizing antibodies generated during natural HIV-1 infection: good news for an HIV-1 vaccine? Nat Med 2009;15:866-70.

[88] Moore PL, Crooks ET, Porter L, Zhu P, Cayanan CS, Grise H, et al. Nature of nonfunctional envelope proteins on the surface of human immunodeficiency virus type 1. J Virol 2006;80:2515-28.

[89] Nabel GJ. Designing tomorrow's vaccines. N Engl J Med 2013;368:551-60.

[90] Hessell AJ, Rakasz EG, Tehrani DM, Huber M, Weisgrau KL, Landucci G, et al. Broadly neutralizing monoclonal antibodies 2F5 and 4E10 directed against the human immunodeficiency virus type $1 \mathrm{gp} 41$ membrane-proximal external region protect against mucosal challenge by simian-human immunodeficiency virus SHIVBa-L. J Virol 2010;84:1302-13.

[91] Burton DR, Hessell AJ, Keele BF, Klasse PJ, Ketas TA, Moldt B, et al. Limited or no protection by weakly or nonneutralizing antibodies against vaginal SHIV challenge of macaques compared with a strongly neutralizing antibody. Proc Natl Acad Sci U S A 2011;108:11181-6.

[92] Pegu A, Yang ZY, Boyington JC, Wu L, Ko SY, Schmidt SD, et al. Neutralizing antibodies to HIV-1 envelope protect more effectively in vivo than those to the CD4 receptor. Sci Transl Med 2014;6:243ra88.

[93] Rudicell RS, Kwon YD, Ko SY, Pegu A, Louder MK, Georgiev IS, et al. Enhanced potency of a broadly neutralizing HIV-1 antibody in vitro improves protection against lentiviral infection in vivo. J Virol 2014:88:12669-82.

[94] Moldt B, Rakasz EG, Schultz N, Chan-Hui PY, Swiderek K, Weisgrau KL, et al. Highly potent HIV-specific antibody neutralization in vitro translates into effective protection against mucosal SHIV challenge in vivo. Proc Natl Acad Sci U S A 2012;109:18921-5.

[95] Kwong PD. Structure-based stabilization of the prefusion closed HIV-1 env trimer [SY05.03]. In: HIV R4P. 2014

[96] Scheid JF, Mouquet H, Ueberheide B, Diskin R, Klein F, Oliveira TY, et al Sequence and structural convergence of broad and potent HIV antibodies that mimic CD4 binding. Science 2011;333:1633-7.

[97] Burton DR, Ahmed R, Barouch DH, Butera ST, Crotty S, Godzik A, et al. A blueprint for HIV vaccine discovery. Cell Host Microbe 2012;12:396-407.

[98] Kwong PD, Mascola JR. Human antibodies that neutralize HIV-1: identification, structures, and B cell ontogenies. Immunity 2012;37:412-25.

[99] Walker LM, Huber M, Doores KJ, Falkowska E, Pejchal R, Julien JP, et al. Broad neutralization coverage of HIV by multiple highly potent antibodies. Nature 2011;477:466-70.

[100] Walker LM, Phogat SK, Chan-Hui PY, Wagner D, Phung P, Goss JL, et al Broad and potent neutralizing antibodies from an African donor reveal a new HIV-1 vaccine target. Science 2009;326:285-9.

101] Wu X, Yang ZY, Li Y, Hogerkorp CM, Schief WR, Seaman MS, et al. Rational design of envelope identifies broadly neutralizing human monoclonal antibodies to HIV-1. Science 2010;329:856-61.

[102] Yu L, Guan Y. Immunologic basis for long HCDR3s in broadly neutralizing antibodies against HIV-1. Front Immunol 2014:5:250.

[103] McGuire AT, Dreyer AM, Carbonetti S, Lippy A, Glenn J, Scheid JF, et al. HIV antibodies, antigen modification regulates competition of broad and narrow neutralizing HIV antibodies. Science 2014;346:1380-3.

[104] Breden F, Lepik C, Longo NS, Montero M, Lipsky PE, Scott JK. Comparison of antibody repertoires produced by HIV-1 infection, other chronic and acute infections, and systemic autoimmune disease. PLOS ONE 2011;6: e16857.

[105] Scheid JF, Mouquet H, Feldhahn N, Seaman MS, Velinzon K, Pietzsch J, et al Broad diversity of neutralizing antibodies isolated from memory B cells in HIV-infected individuals. Nature 2009;458:636-40.

[106] Guenaga J, de Val N, Tran K, Feng Y, Satchwell K, Ward AB, et al. Wellordered trimeric HIV-1 subtype B and C soluble spike mimetics generated by negative selection display native-like properties. PLOS Pathog 2015;11 e1004570.

[107] Pugach P, Ozorowski G, Cupo A, Ringe R, Yasmeen A, de Val N, et al. A native-like SOSIP.664 trimer based on a HIV-1 subtype B env gene. J Virol 2015;89:3380-95.

[108] West Jr AP, Scharf L, Scheid JF, Klein F, Bjorkman PJ, Nussenzweig MC. Struc tural insights on the role of antibodies in HIV-1 vaccine and therapy. Cell 2014; $156: 633-48$.

[109] McCoy LE, Weiss RA. Neutralizing antibodies to HIV-1 induced by immunization. J Exp Med 2013;210:209-23.

[110] Huang X, Jin W, Hu K, Luo S, Du T, Griffin GE, et al. Highly conserved HIV1 gp120 glycans proximal to CD4-binding region affect viral infectivity and neutralizing antibody induction. Virology 2012;423:97-106.

[111] Quinnan Jr GV, Zhang P, Dong M, Chen H, Feng YR, Lewis M, et al. Neutraliz ing antibody responses in macaques induced by human immunodeficiency virus type 1 monovalent or trivalent envelope glycoproteins. PLOS ONE 2013;8:e59803.

[112] Kovacs JM, Nkolola JP, Peng H, Cheung A, Perry J, Miller CA, et al. HIV-1 envelope trimer elicits more potent neutralizing antibody responses than monomeric gp120. Proc Natl Acad Sci U S A 2012:109:12111-6.

[113] Bricault CA, Kovacs JM, Nkolola JP, Yusim K, Giorgi EE, Shields JL, et al A multivalent clade C HIV-1 Env trimer cocktail elicits a higher magnitude of neutralizing antibodies than any individual component. J Virol 2015;89:2507-19.

[114] Santra S, Muldoon M, Watson S, Buzby A, Balachandran H, Carlson KR et al. Breadth of cellular and humoral immune responses elicited in rhesus monkeys by multi-valent mosaic and consensus immunogens. Virology 2012;428:121-7. 
[115] Bonsignori M, Alam SM, Liao HX, Verkoczy L, Tomaras GD, Haynes BF, et al. HIV-1 antibodies from infection and vaccination: insights for guiding vaccine design. Trends Microbiol 2012;20:532-9.

[116] Liao HX, Lynch R, Zhou T, Gao F, Alam SM, Boyd SD, et al. Co-evolution of a broadly neutralizing HIV-1 antibody and founder virus. Nature 2013;496:469-76.

[117] Doria-Rose NA, Schramm CA, Gorman J, Moore PL, Bhiman JN, DeKosky BJ, et al. Developmental pathway for potent V1V2-directed HIV-neutralizing antibodies. Nature 2014;509:55-62.

[118] Jardine J, Julien JP, Menis S, Ota T, Kalyuzhniy O, McGuire A, et al. Rational HIV immunogen design to target specific germline B cell receptors. Science 2013;340:711-6.

[119] Johnson PR, Schnepp BC, Zhang J, Connell MJ, Greene SM, Yuste E, et al. Vector-mediated gene transfer engenders long-lived neutralizing activity and protection against SIV infection in monkeys. Nat Med 2009;15:901-6.

[120] Schnepp BC, Johnson PR. Adeno-associated virus delivery of broadly neutralizing antibodies. Curr Opin HIV AIDS 2014;9:250-6.

[121] Balazs AB, Chen J, Hong CM, Rao DS, Yang L, Baltimore D. Antibody-based protection against HIV infection by vectored immunoprophylaxis. Nature 2012;481:81-4.

[122] Balazs AB, Ouyang Y, Hong CM, Chen J, Nguyen SM, Rao DS, et al. Vectored immunoprophylaxis protects humanized mice from mucosal HIV transmission. Nat Med 2014;20:296-300

[123] Tongo M, Burgers WA. Challenges in the design of a $\mathrm{T}$ cell vaccine in the context of HIV-1 diversity. Viruses 2014:6:3968-90.

[124] McDermott AB, Koup RA. CD8(+) T cells in preventing HIV infection and disease. AIDS 2012;26:1281-92.

[125] McMichael AJ, Haynes BF. Lessons learned from HIV-1 vaccine trials: new priorities and directions. Nat Immunol 2012;13:423-7.

[126] Korber BT, Letvin NL, Haynes BF. T-cell vaccine strategies for human immunodeficiency virus, the virus with a thousand faces. J Virol 2009;83:8300-14

[127] Parks CL, Picker LJ, King CR. Development of replication-competent viral vectors for HIV vaccine delivery. Curr Opin HIV AIDS 2013;8:402-11

[128] Excler JL, Parks CL, Ackland J, Rees H, Gust ID, Koff WC. Replicating viral vectors as HIV vaccines: summary report from the IAVI-sponsored satellite symposium at the AIDS vaccine 2009 conference. Biologicals 2010;38:511-21.

[129] Koup RA, Graham BS, Douek DC. The quest for a T cell-based immune correlate of protection against HIV: a story of trials and errors. Nat Rev Immunol 2011;11:65-70

[130] Liu J, O’Brien KL, Lynch DM, Simmons NL, La Porte A, Riggs AM, et al. Immune control of an SIV challenge by a T-cell-based vaccine in rhesus monkeys. Nature 2009;457:87-91.

[131] McElrath MJ, De Rosa SC, Moodie Z, Dubey S, Kierstead L, Janes H, et al. HIV-1 vaccine-induced immunity in the test-of-concept step study: a case-cohort analysis. Lancet 2008;372:1894-905

[132] Rolland M, Tovanabutra S, deCamp AC, Frahm N, Gilbert PB, Sanders-Buell E, et al. Genetic impact of vaccination on breakthrough HIV-1 sequences from the STEP trial. Nat Med 2011;17:366-71.

[133] Fitzgerald DW, Janes $H$, Robertson M, Coombs R, Frank I, Gilbert P, et at. An Ad5-vectored HIV-1 vaccine elicits cell-mediated immunity but does not affect disease progression in HIV-1-infected male subjects: results from a randomized placebo-controlled trial (the step study). J Infect Dis 2011:203:765-72

[134] Li F, Finnefrock AC, Dubey SA, Korber BT, Szinger J, Cole S, et al. Mapping HIV-1 vaccine induced T-cell responses: bias towards less-conserved regions and potential impact on vaccine efficacy in the Step study. PLOS ONE 2011;6:e20479.

[135] Reynolds MR, Weiler AM, Piaskowski SM, Piatak Jr M, Robertson HT, Allison DB, et al. A trivalent recombinant Ad5 gag/pol/nef vaccine fails to protect rhesus macaques from infection or control virus replication after a limitingdose heterologous SIV challenge. Vaccine 2012;30:4465-75.

[136] Qureshi H, Ma ZM, Huang Y, Hodge G, Thomas MA, DiPasquale J, et al Low-dose penile SIVmac251 exposure of rhesus macaques infected with adenovirus type 5 (Ad5) and then immunized with a replication-defective Ad5-based SIV gag/pol/nef vaccine recapitulates the results of the phase IIb Step trial of a similar HIV-1 vaccine. J Virol 2012;86:2239-50.

[137] Letvin NL, Rao SS, Montefiori DC, Seaman MS, Sun Y, Lim SY, et al. Immune and genetic correlates of vaccine protection against mucosal infection by SIV in monkeys. Sci Transl Med 2011;3:81ra36.

[138] Bakari M, Aboud S, Nilsson C, Francis J, Buma D, Moshiro C, et al. Broad and potent immune responses to a low dose intradermal HIV-1 DNA boosted with HIV-1 recombinant MVA among healthy adults in Tanzania. Vaccine 2011;29:8417-28.

[139] Ratto-Kim S, Currier JR, Cox JH, Excler JL, Valencia-Micolta A, Thelian D, et al. Heterologous prime-boost regimens using rAd35 and rMVA vectors elicit stronger cellular immune responses to HIV proteins than homologous regimens. PLOS ONE 2012; $:$ :e45840.

[140] Santra S, Liao HX, Zhang R, Muldoon M, Watson S, Fischer W, et al. Mosaic vaccines elicit CD8+ T lymphocyte responses that confer enhanced immune coverage of diverse HIV strains in monkeys. Nat Med 2010;16:324-8.

[141] Barouch DH, O’Brien KL, Simmons NL, King SL, Abbink P, Maxfield LF, et al Mosaic HIV-1 vaccines expand the breadth and depth of cellular immune responses in rhesus monkeys. Nat Med 2010;16:319-23.

[142] Letourneau S, Im EJ, Mashishi T, Brereton C, Bridgeman A, Yang $H$, et al. Design and pre-clinical evaluation of a universal HIV-1 vaccine. PLOS ONE 2007;2:e984

[143] Rolland M, Nickle DC, Mullins JI. HIV-1 group M conserved elements vaccine. PLOS Pathog 2007; 3:e157.

[144] Liu Y, McNevin J, Rolland M, Zhao H, Deng W, Maenza J, et al. Conserved HIV-1 epitopes continuously elicit subdominant cytotoxic T-lymphocyte responses. J Infect Dis 2009;200:1825-33.

[145] Kulkarni V, Valentin A, Rosati M, Rolland M, Mullins JI, Pavlakis GN, et al. HIV-1 conserved elements p24CE DNA vaccine induces humoral immune responses with broad epitope recognition in macaques. PLOS ONE 2014;9: e111085.

[146] Stephenson KE, SanMiguel A, Simmons NL, Smith K, Lewis MG, Szinger JJ, et al. Full-length HIV-1 immunogens induce greater magnitude and comparable breadth of T lymphocyte responses to conserved HIV-1 regions compared with conserved-region-only HIV-1 immunogens in rhesus monkeys. J Viro 2012;86:11434-40

[147] Clutton G, Carpov A, Parks CL, Dean HJ, Montefiori DC, Hanke T. Optimizing parallel induction of HIV type 1-specific antibody and T-cell responses by multicomponent subunit vaccines. AIDS 2014;28:2495-504.

[148] Ondondo B, Abdul-Jawad S, Bridgeman A, Hanke T. Characterization of T-cell responses to conserved regions of the HIV-1 proteome in BALB/C mice. Clin Vaccine Immunol 2014;21:1565-72.

[149] Koopman G, Beenhakker N, Nieuwenhuis I, Doxiadis G, Mooij P, Drijfhout JW, et al. DNA/long peptide vaccination against conserved regions of SIV induces partial protection against SIVmac251 challenge. AIDS 2013;27: 2841-51.

[150] Hayton EJ, Rose A, Ibrahimsa U, Del Sorbo M, Capone S, Crook A, et al Safety and tolerability of conserved region vaccines vectored by plasmid DNA simian adenovirus and modified vaccinia virus ankara administered to human immunodeficiency virus type 1-uninfected adults in a randomized, single-blind phase I trial. PLOS ONE 2014;9:e101591.

[151] Borthwick N, Ahmed T, Ondondo B, Hayes P, Rose A, Ebrahimsa U, et al. Vaccine-elicited human $\mathrm{T}$ cells recognizing conserved protein regions inhibit HIV-1. Mol Ther 2014;22:464-75.

[152] Hansen SG, Ford JC, Lewis MS, Ventura AB, Hughes CM, Coyne-Johnson L, et al. Profound early control of highly pathogenic SIV by an effector memory T-cell vaccine. Nature 2011;473:523-7.

[153] Hansen SG, Piatak Jr M, Ventura AB, Hughes CM, Gilbride RM, Ford JC, et al. Immune clearance of highly pathogenic SIV infection. Nature 2013;502:100-4

[154] Barouch DH, Michael NL. Accelerating HIV-1 vaccine efficacy trials. Cell 2014:159:969-72. 